\section{OS SENTIDOS DO QUEREMISMO: \\ disputas políticas em torno do conceito na redemocratização de 1945}

The meanings of queremismo: political debates on the concept during the redemocratization of 1945
Jefferson José

\section{QUELER}

Universidade Federal de Ouro Preto (UFOP)

jeffquelerahotmail.com

\section{RESUMO}

Neste artigo, pretende-se analisar os sentidos do conceito de queremismo, durante a redemocratização de 1945. O termo aparece normalmente na historiografia para descrever as manifestações em prol de Vargas naquele ano. Entre elas, surgiam apelos para sua candidatura presidencial ou sua participação em Assembleia Constituinte, sob o slogan "Queremos Getúlio". Entretanto, é possível identificar sua cunhagem nos debates políticos do periodo. Procurando seguir a problemática da história dos conceitos, investigarei seu surgimento em jornais da época, seja em veículos de oposição, seja em periódicos ligados ao Estado Novo. Dessa forma, buscarei indicar a trajetória do termo queremismo, situando-o historicamente, bem como seus usos políticos por setores da população que apoiavam Getúlio Vargas.

Palavras-chave: Queremismo; Redemocratização de 1945; Imprensa; Liberalismo; Getúlio Vargas.

\begin{abstract}
This article intends to investigate the senses of queremismo as a concept during the redemocratization in 1945. It normally appears in the historiography to describe the manifestations supporting Vargas. These bore demands concerning his candidacy to presidency or his participation in the formulation of the new Constitution under the slogan "Queremos Getúlio". However it is possible to demonstrate how the term was built through the political debates at the time. By pursuing an approach related to the history of concepts, I will investigate how it emerged in newspapers from oppositionists and supporters of Estado Novo. Thus queremismo, as a historical creation, reveals a trajectory and diverse political uses. Some of these had to do with social groups that supported Getúlio Vargas'continuity in the centre of political power.
\end{abstract}

Keywords: Queremismo; Redemocratization in 1945; Press; Liberalism; Getúlio Vargas. 


\section{Introdução}

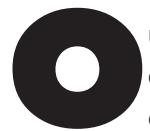

uso do termo queremismo para descrever as manifestações populares a favor de Getúlio Vargas, em 1945, é bastante cristalizado na historiografia. Entretanto, é possível indicar como tal conceito, longe de possuir um sentido neutro e fixo, foi então instrumento central da luta política. As páginas de diversos veículos da imprensa indicam que ele surgiu como um neologismo e, em etapa posterior, foi ressignificado numerosas vezes, seja para desmobilizar os novos sujeitos que adentravam a arena política, seja para conferir-lhes unidade nas lutas em defesa de seus interesses. Conforme veremos, num primeiro momento, vozes da imprensa liberal, diante de multidões esparsas e pouco articuladas entre si que clamavam pela permanência de Vargas na presidência, procuraram construir linguisticamente um inimigo político coeso, o queremismo. Artifício destinado a desqualificar tais manifestações, o termo foi, porém, paulatinamente incorporado de forma positiva pelos sujeitos que delas participavam. Jornais oficiosos e, por vezes, os próprios periódicos empenhados em suprimir a participação popular divulgavam posicionamentos simpáticos ao então presidente. Em muitos deles, o referido conceito emergia como elemento privilegiado da luta política, objetivando concretizar um movimento social em escala nacional.

\section{O queremismo e a criação do inimigo político}

O cenário inicial desta investigação é uma ditadura abalada. Em 1945, o Estado Novo começava a perder força. No plano internacional, o engajamento do Brasil ao lado dos Aliados contra os países do Eixo contribuiu para o questionamento do regime. Afinal, seu caráter autoritário, em muito semelhante ao aparato nazifascista, foi cada vez mais contestado pelo apoio brasileiro a países sob governo democrático. No plano interno, diversas manifestações da sociedade civil clamavam pela abertura política. Em janeiro daquele ano, um grupo de intelectuais organizou o I Congresso Brasileiro de Escritores, por meio do qual reivindicavam "completa liberdade de expressão" e um governo eleito por "sufrágio universal, direto e secreto". No mês seguinte, o jornal oposicionista Correio da Manhã rompeu novamente a censura, ao publicar entrevista polêmica com o escritor e político José Américo de Almeida, em que este pedia eleições presidenciais. Várias fissuras, aos poucos, minaram a sustentação do regime autoritário. Em meio a tais pressões, o presidente Getúlio Vargas comprometeu-se com a redemocratização do país (ABREU et al., 2001).

Os partidos políticos, até então banidos sob a acusação de causar divisões e desordens, ressurgiram. Uma ampla frente de opositores de Vargas, desde liberais conservadores até socialistas, uniu-se momentaneamente para fundar a União Democrática Nacional (UDN). Logo, um candidato à Presidência emergiu de suas fileiras: o brigadeiro Eduardo Gomes. Considerado herói de 1922 por muitos, sobrevivente dos "18 do Forte", organizador do Correio Aéreo Nacional e articulador da defesa aérea do Atlântico, durante a Segunda Guerra Mundial, ele era uma figura capaz de atrair o apoio e a simpatia das camadas 
médias com seu moralismo e aura de virtudes cívicas e cristãs. Em torno dele, agruparam-se também membros das Forças Armadas e intelectuais, com a exceção dos trabalhadores (BENEVIDES, 1981, p. 42-45). Muitos liberais udenistas consideravam essa ausência ou rejeição um sinal de imaturidade política desses sujeitos.

Na disputa pelo voto operário, outros atores competiam entre si. O Partido Social Democrático (PSD), oriundo da união entre interventores do Estado Novo e grandes proprietários rurais, apoiou o general Eurico Gaspar Dutra, ex-ministro da Guerra. Os comunistas, em seu breve periodo de atuação legal, concentraram suas expectativas no engenheiro ledo Fiúza. De qualquer modo, a candidatura que pulsava entre grande parte da população era a de Vargas, por mais que este se negasse publicamente a concorrer. Para a surpresa e a decepção das elites liberais, a partir de maio, milhares de trabalhadores saíram às ruas pedindo "Nós queremos Getúlio". Daí o termo "queremismo", surgido naquelas circunstâncias para enquadrar tal fenômeno, conforme veremos. As manifestações e comícios em prol de Vargas contaram com o suporte do Ministério do Trabalho; o ministro Alexandre Marcondes Filho ofereceu-lhes apoio tácito. Empresários financiaram tais movimentos, com destaque para Hugo Borghi. Os comunistas também chegaram a apoiá-las (ABREU et al., 2001). Escorado em grande parte nessas manifestações e na estrutura sindical corporativista, surgiu o Partido Trabalhista Brasileiro (PTB). Em meio a esse quadro, cientistas sociais e historiadores, durante muito tempo, vislumbraram essas manifestações como despidas de autonomia ou consciência de classe. Nesse sentido, um trabalho muito influente é o de Maria do Carmo Campello de Souza. Sobre a transição democrática de 1945, a autora afirma tratar-se de mero "reflexo interno" do cenário internacional, sem a presença de "qualquer movimento contestatório de amplas bases sociais, ou inspirado em metas ideológicas" (SOUZA, 1976, p. 105-108).

Contudo, interpretações como essa, ainda que tenham sido importantes e sofisticadas no momento de sua publicação, já foram problematizadas. Em dissertação de mestrado defendida em 1984, Elza Borghi de Almeida Cabral - respaldando-se em jornais e discursos de lideranças políticas e, provavelmente, partindo de preocupações relacionadas às lutas pela redemocratização em curso na primeira parte da década de 1980 -, sustentou que os simpatizantes do varguismo, em 1945, constituíram significativa experiência de aprendizado político, seja por meio de suas manifestações nas ruas ou pela constituição de suas demandas para pressionar o poder público; em especial, pela defesa da candidatura de Vargas para as eleições presidenciais e, posteriormente, de sua participação em Assembleia Nacional Constituinte. Contudo, a autora assevera que eles encontraram sérios limites para sua representação, ao seguirem líderes provenientes das camadas médias e da burguesia, os horizontes destas últimas, podendo ser percebidos na ênfase no desenvolvimento harmônico das relações entre o capital e o trabalho (CABRAL, 1984, p. 191). Portanto, Cabral pressupõe posições políticas que os trabalhadores deveriam ter tido. Por outro lado, não teriam eles compartilhado alguns de seus interesses com outros grupos sociais? 
Em trabalho mais recente, Jorge Ferreira corrobora a ideia de que tais manifestações representaram significativo aprendizado político. Porém, o autor defende que elas canalizaram interesses efetivos dos trabalhadores, especialmente sua valorização simbólica no discurso oficial e a defesa da legislação trabalhista. ${ }^{1}$ Sua pesquisa baseia-se principalmente na análise de seções da chamada grande imprensa compradas por participantes dos movimentos pró-Vargas em 1945, assim como do jornal O Radical, favorável ao presidente à época. Um exemplo importante e representativo, publicado neste último em 15 de agosto de 1945, aparece na opinião de Alcebíades V. Tôrres, operário da fábrica Cerâmica Brasileira e líder de comitê varguista, representante de 600 empregados da empresa, bem como de moradores dos morros da Mangueira e do Jacarezinho. Em ocasião em que contestou a legislação que impedia a candidatura do presidente, Tôrres discorreu: "Se isso é crime [...] não existe mais mentira do que a democracia! Se estamos no caminho de liberdades populares, como se apregoa, por que evitar que o povo escolha e eleja aquele que é o chefe da pobreza, o amigo dos humildes que nos garantiu" (FERREIRA, 2005, p. 29). Como se vê, tal líder pretende conduzir Vargas à frente de um regime democrático, na condição de fiador de benefícios percebidos como conquistados, uma apropriação seletiva do ideário liberal, especialmente da noção de soberania popular.

Concordo com essa reavaliação da redemocratização de 1945. Ela não foi simplesmente um "reflexo interno" do cenário internacional, uma transição somente pactuada pelo alto ou dominada inteiramente pelo oficialismo. Tampouco foi palco da reedição de mero personalismo na política brasileira, mesmo que a figura carismática de Vargas tenha tido peso decisivo. Entre os trabalhadores, havia evidentemente quem defendesse a permanência deste último na Presidência com ou sem eleições. Porém, o argumento de que todos eles quisessem o tempo todo perpetuar o ditador no poder provinha das fileiras liberais, como uma forma de desqualificá-los. Tal posicionamento deixa de lado toda a participação ativa dos trabalhadores em prol da organização de eleições e de uma Assembleia Nacional Constituinte. Se não partirmos de um modelo idealizado de democracia ou participação política, talvez seja possível fornecer mais subsídios para a interpretação de que houve participação política concreta dos referidos sujeitos.

O balanço e as reflexões de Jorge Ferreira, acerca do tratamento crítico do populismo como conceito, contribuem para essa perspectiva. $O$ autor procura, antes de mais nada, traçar a história do referido termo, e demonstra como ele foi associado, na América Latina, à notável migração de trabalhadores rurais para os centros urbanos durante a primeira metade do século XX. Na percepção de muitos críticos e analistas, tais pessoas não eram capazes de realizar ações coletivas ou, segundo um viés marxista específico, não tinham "consciência de classe", tornando-se presas fáceis da manipulação de lideranças carismáticas. Essa situação, porém, seria remediada no futuro, em estágio em que o desenvolvimento econômico dos países latino-americanos supostamente permitiria a consolidação de eleitores capazes de escolher devidamente seus representantes. Tal perspectiva subsidiou o trabalho de influentes sociólogos, como Francisco Weffort e Octavio lanni, os 
quais advogaram a existência do populismo na política brasileira (FERREIRA, 2001, p. 59125). Após identificar essa matriz interpretativa na constituição da noção de populismo, Jorge Ferreira demonstra como esta última vem sendo problematizada nos últimos anos.

Diversos estudos, em diálogo com distintas correntes teórico-metodológicas, apontaram o atendimento de interesses concretos dos trabalhadores diante de políticos tidos como "populistas". A chamada história cultural indicava que trabalhadores e camponeses, e não apenas as elites, produziam valores, crenças e códigos comportamentais. Os trabalhos do historiador marxista inglês E. P. Thompson questionavam análises teleológicas que insistiam na ideia de consciências desviadas. E a perspectiva de Michel Foucault, de que a racionalidade e a técnica eram mobilizadas para controlar os operários, mostrava seus limites, na medida em que estes últimos podiam se contrapor a elas (FERREIRA, 2001, p. 59-125). Assim, o referido trabalho de Ângela de Castro Gomes, inspirado pelas formulações de E. P. Thompson, chamou a atenção para os ganhos materiais e simbólicos dos trabalhadores frente ao trabalhismo e ao primeiro governo Vargas. Jorge Ferreira, em seu referido texto sobre o processo de redemocratização em 1945, seguiu caminho semelhante, procurando conjugar elementos da história cultural à sua investigação. De modo a aprofundar essas interpretações, penso, a história dos conceitos poderia acrescentar elementos para uma melhor compreensão do protagonismo dos trabalhadores naquela conjuntura, pois os usos do termo queremismo parecem ter desempenhado papel central em suas lutas e reivindicações.

Segundo Koselleck (2006, p. 102-203), certas terminologias podem desempenhar importante papel na produção e na orientação de ações políticas. Nesse sentido, o autor afirma que, desde pelo menos a Revolução Francesa, diminuiu o conteúdo empírico de muitos conceitos. Ao mesmo tempo, aumentou proporcionalmente a exigência de realização futura contida neles. Daí o surgimento de uma série de "ismos" (conservadorismo, liberalismo, socialismo), com o propósito de ordenar e mobilizar as massas estruturalmente desarticuladas. A noção de queremismo, contudo, não se encaixa numa trajetória linear. Como veremos, seus primeiros usos procuravam condenar e mesmo desmobilizar os simpatizantes de Vargas, ao passo que sua utilização com o intuito de mobilização surgiu apenas no curso das lutas políticas de 1945.

O aparecimento do termo, durante a redemocratização, está intimamente associado ao liberalismo de segmentos das elites brasileiras. Torna-se muito difícil, senão impossível, identificar seu primeiro uso, pois ele parece ser resultado de uma ação política não planejada, fruto do calor da hora. Não se trata de uma criação organizada e racionalizada, restrita a alguns poucos intelectuais. Pierre Rosanvallon enfrentou situação semelhante, ao analisar as relações entre as noções de liberalismo e democracia ao longo da Revolução Francesa. Segundo ele, elas não devem ser reduzidas apenas a debates entre Rousseau e Montesquieu. Outros significados também precisam ser buscados em autores que tomaram contato com suas ideias: nas petições enviadas à Assembleia, nas brochuras, nos libelos 
e nos debates parlamentares (ROSANVALLON, 1995, p. 17). Entendendo assim a produção de conceitos como um processo dinâmico e repleto de apropriações e ressignificações, diversos jornais atuantes, em 1945, indicam como foi travada verdadeira batalha de palavras para se definir os sentidos de queremismo.

No Brasil da primeira metade do século XX, significativa parcela da imprensa herdeira dos ideais do lluminismo propunha registrar os fatos objetivamente e esclarecer a opinião pública. Porém, um claro propósito de controle social e um combate acirrado à ampliação da esfera pública surgiam em suas páginas. Nesse sentido, ela não apenas construía e comentava os fatos, como também buscava intervir na vida social, verdadeiro agente da história (CAPELATO, 1988, p. 12-13). A partir da década de 1930, o jornalismo torna-se cada vez mais uma atividade empresarial. O jornal de outrora, ligado à visão personalista de seu proprietário, abria caminho para o jornal-empresa (BAHIA, 1990, p. 203). Os anos seguintes assistiram a um notável processo de concentração das empresas jornalísticas, com o desaparecimento de pequenos jornais e a formação de conglomerados e periódicos de alta circulação. Estes dependiam fortemente de verbas publicitárias e da importação de papel, o que impunha sérias limitações aos conteúdos de suas mensagens (SODRÉ, 1999, p. 388389). Para os propósitos deste texto, abordaremos particularmente jornais do eixo Rio-São Paulo. Neles, é possível encontrar veículos de oposição a Vargas na época da redemocratização, bem como periódicos oficiosos que defenderam seu legado, o que pode fornecer pistas sobre os debates travados em torno de conceitos e práticas políticas.

O termo queremismo aparece justamente nos debates políticos de 1945. Ele surge quase sempre entre aspas, como que indicando sua novidade ou imprecisão. Não se tratava apenas de utilizar a palavra para confundir e ofuscar os getulistas. Tratava-se também de empregá-la para abrir caminho para soluções de força, no sentido de interromper as demandas e ações deles. É o que aponta coluna do jornal Diário Carioca, capitaneado por José Eduardo de Macedo Soares e entusiasta da candidatura do brigadeiro Eduardo Gomes, em 21 de agosto. ${ }^{2}$ Nela, o colunista Joaquim Sales alegou que o termo foi "patenteado nos meios inacessíveis do Palácio Guanabara", algo improvável, tendo em vista o grau de sua recusa que poderemos notar em periódicos oficiais. De qualquer modo, ele reconheceu sua novidade, "neologismo que aos aproveitadores e especuladores tanto seduz, e aos bons brasileiros sugere perspectivas sinistras" (p. 4). Em outras palavras, uma ameaça a ser combatida. Sua estratégia para tanto emergiu em seu apelo para que o general Góis Monteiro interviesse. A repressão das manifestações foi claramente solicitada. Afinal, o "queremismo" é "uma gramínea daninha, chamada tiririca, que só desaparece quando se the arrancam as raízes sem dó nem piedade". Enquanto ela perdurar, defende o colunista, o "Estado Novo terá vida, ninguém acabará com ele" (p. 4). Como se pode observar, a definição do termo não é neutra. Seu sentido negativo ou metafórico visa não apenas a deslegitimar os atos públicos em prol de Vargas, mas também eliminá-los por meio de uma intervenção militar. 
As metáforas empregadas para atacar os manifestantes varguistas não pararam por aí. O Jornal do Brasil, periódico carioca então na oposição a Vargas e que manifestava simpatia pela candidatura udenista, publicou coluna de Hélio Silva em 6 de setembro propondo delinear a "etio-patologia" do "queremismo". Eis o diagnóstico: "Massas trabalhistas longamente trabalhadas pela propaganda e ainda agora manejadas, por meio dos agentes do Ministério do Trabalho, pelos interessados na continuação desse estado de coisas" ( $p$. 5). A equiparação dos referidos sujeitos a uma doença é clara, tratados como agentes patogênicos interessados na continuidade da ditadura. De forma semelhante, o Correio da Manhã, órgão da antiga capital federal sob o controle da família Bittencourt e francamente brigadeirista, discorreu em 9 de junho sobre a expansão das manifestações varguistas para outras partes do Brasil: "A Paraíba, que era um dos raros Estados por onde a praga do curuquerê do 'queremismo' ainda se não havia alastrado, foi afinal invadida pelo mal" ( $p$. 10). Tiradas do mundo da biologia e da medicina, tais imagens evocam supostos males que, pressupõe-se, deviam ser sanados, curados, ou seja, eliminados do cenário político. ${ }^{3}$

A elasticidade do conceito era tal, que seu uso transcendeu a seara política e atingiu o universo da cultura. Em 9 de outubro, o jornal carioca Diário de Notícias, fundado por Orlando Ribeiro Dantas e partidário da candidatura de Eduardo Gomes, identificou um "queremismo radiofônico": os programas de rádio com conteúdo cultural considerado de baixo nível. Segundo opinião sustentada na coluna, tal veículo apresentara traços do suposto fenômeno muito antes de o "neologismo entrar para o dicionário da politicagem nacional". Em outras palavras, o "queremismo do 'broadcasting' e do samba, das novelas, dos calouros e humoristas. As suas hostes são formadas pelos frequentadores de auditórios, ouvintes sem cultura, cantores e redatores ignorantes, locutores-palhaços e patrocinadores boçais" (p. 2, segunda secção). O elitismo que perpassa a construção negativa do termo torna-se bastante explícito. O suposto baixo nível cultural de tais programas, ao ser enquadrado nele, reforça a ideia de que os indivíduos localizados em suas fileiras não possuíam capacidade para se expressar politicamente.

O questionamento do uso amplo e impreciso da terminologia veio à tona nos debates públicos. É o que sugere a coluna do jornal carioca Gazeta de Notícias, então partidário da candidatura Dutra. Em 7 de agosto, uma reportagem procurou reproduzir a argumentação dos descontentes com o significado do rótulo: "O termo 'queremismo' está sendo agora empregado num sentido abusivo por parte daqueles que precisam se agarrar a todo e qualquer recurso para atacar o governo e seus homens". Ademais, a mera simpatia pessoal ou admiração pela obra do chefe do governo seriam suficiente para ver-se taxado de 'queremista'. Contrapondo-se ferrenhamente a essas perspectivas, o periódico é taxativo: "Só por obtusa fé se pode pensar assim". Como forma de sustentar sua opinião, comentou episódio que teria se passado no Hipódromo da Gávea, quando algumas pessoas teriam manifestado simpatia por Vargas e desrespeitado o hino nacional, baixo nível cultural ou civilizatório que justificaria plenamente o uso do termo. 
Sobre a contundência do elitismo desses ataques, Barrington Moore Jr. lembra que é muito importante, do ponto de vista de um grupo dominante, inibir quaisquer formas de autoestima ou orgulho entre as camadas sociais mais baixas, uma forma de conservar a ordem vigente (MOORE JUNIOR, 1978, p. 77). Assim, subjacente a essa disputa conceitual, encontra-se a ascensão social de novos grupos, bem como a resistência dos antigos grupos dominantes. Evidentemente, não se trata de caso único na história. Norbert Elias, em seu livro Os Alemães, indica como a Alemanha derrotada na Primeira Guerra Mundial foi palco da subida de trabalhadores a posições das quais eles nunca haviam participado. O sucessor do cáiser, por exemplo, fora um antigo fabricante de arreios. Segundo o sociólogo, muitos membros da "boa sociedade" alemã encararam essa mudança como uma insuportável ferida em seus sentimentos de autoestima. Uma situação em que eles se viram colocados no mesmo nível de poder e status daqueles sujeitos que antes desprezavam, "grupos de baixa extração social, de menor valor humano, a ralé" (ELIAS, 1997, p. 170). Guardadas as devidas proporções, essas observações talvez iluminem o caso ora analisado.

Na conjuntura da redemocratização brasileira de 1945, um grande contingente de trabalhadores almejava escolher o próprio candidato à Presidência da República. Esse posicionamento os fazia avançar em direção a assuntos e decisões outrora tratados com mais exclusividade pelas elites. Aspectos da resistência destas últimas a esse processo podem ser entrevistos em reportagem do jornal Diário Carioca de 29 de julho de 1945. Trata-se da cobertura da chegada de dois emissários do "queremismo" gaúcho ao Rio de Janeiro para estruturar um partido nacional para lançar a candidatura de Vargas. $O$ teor inicial da reportagem deixa bem claro o distanciamento social sentido pelo repórter em relação aos dois sujeitos:

O repórter foi a única pessoa que foi recebê-los no aeroporto e
quando eles apontaram no grupo de passageiros que descera
do aparelho não teve dificuldades em reconhecê-los. Não havia
retrato, não havia descrição, nenhum dado para identificação. Mas
esta gente conhece-se à distância.
- O Dr. Jaime Boa Vista e o Sr. Valdir Rodrigues? [...] o repórter
já estava dentro de um táxi com os dois delegados gaúchos do
queremismo eleitoral a caminho da rua Benjamin Constant, 28,
casa de um irmão do Dr. Jayme Boa Vista, que em conversa soube-
se ser ex-ator da Companhia Jaime Costa. Lá, viu-se que não era
bem casa: era quarto numa pensão, onde ficaram as malas dos dois
próceres, e onde o mano não se encontrava. Voltou o táxi à cidade,
para o café de atores desempregados, sub-jornalistas e caftens (p.
1-2).

Não se sabe se o repórter os identificou pelas roupas, pela fala ou pela postura corporal. De algum modo, observou neles alguma distinção de classe. Sobre as instalações dos emissários, fica evidente sua aversão à pensão ou ao café que ambos utilizaram. Algo indigno da posição do jornalista, coisa de ralé. Essa gente, para seu desgosto, pretendia representar um amplo grupo de eleitores. É curioso o modo como ele os interroga sobre a nomenclatura das manifestações varguistas no Rio Grande do Sul, bem como a resposta que recebe: 


\begin{abstract}
-"Queremos"? Chama-se assim também lá? Também entre os "queremistas"?

- Chama-se assim em toda parte. Os mais íntimos, lá nos pagos, chamam de "quero-quero". Pois o Rio Grande do Sul é todo do 'quero-quero'. Há dois: o nosso e o do PSD. O nosso é dos que acreditam poder levar a candidatura Getúlio Vargas às urnas; o do PSD é o dos que estão com o Dutra porque acham que o Getúlio não aceita a candidatura, e, no caso, o Dutra existe apenas à custa do prestígio de Getúlio (p. 1-2).
\end{abstract}

Como podemos notar a partir da fala de líderes das manifestações, "queremistas" ou "queremismo" eram, pelos menos a princípio, expressões utilizadas apenas pelos seus detratores, o que inclui o repórter do Diário Carioca. Os dois sujeitos nelas envolvidos empregam uma pluralidade de nomes para se referir aos apoiadores de Vargas, além de apresentarem nuances de orientações entre os manifestantes. Não havia nenhum movimento unificado em torno de tal rótulo até então.

Esse exemplo guarda semelhanças com a noção de tenentismo. Esta foi formulada pela elite paulista no calor das lutas políticas do início do século XX, com o propósito de criar um inimigo. Apesar de o termo ser amplamente empregado pela historiografia para nomear os movimentos conhecidos como "Os Dezoito do Forte" ou a "Coluna Prestes", ocorridos na década de 1920, sua cunhagem ocorreu somente entre os anos de 1930 e 1932. Como demonstra a pesquisa de Vavy Pacheco Borges, em jornais da época, as práticas e as falas ditas tenentistas não se identificavam como tais, nem eram homogêneas, nem possuíam unidade, o que problematiza a ideia de um movimento unificado, organizado e autoconsciente - como também parece ser o caso de queremismo num primeiro momento. A construção do conceito de tenentismo estava intimamente relacionada com a ascensão de Vargas ao poder em 1930. Entre as primeiras medidas de seu governo, interventores foram enviados aos estados (muitos provindos das fileiras das Forças Armadas), alijando a elite paulista de parcela significativa de seu poder. Por isso, esta última passou a tratá-los como militares intrometendo-se indevidamente na política. Como forma de atacá-los em seus órgãos de imprensa, ela inventou novos sujeitos, "os tenentes", e um novo fenômeno, "o tenentismo" (BORGES, 1992, P. 145).

Dessa forma, os primeiros sentidos de queremismo parecem estar relacionados à construção de um inimigo político. Segundo Edelman (1988, p. 66-70), a construção linguística deste último pode cumprir o papel de suscitar paixões, medos e esperanças. Igualmente, o delineamento de tal ameaça pode favorecer a formação ou a ampliação de uma aliança contra ela. Essa figura é talhada com traços inerentemente maus, patológicos e imorais, não importando o sentido de suas ações. Ela sinaliza que o oponente não deve ser simplesmente combatido, mas também destruído. $O$ avanço dos trabalhadores rumo a uma maior participação na esfera pública, no momento da redemocratização de 1945 , provocou medo e ressentimento entre as elites. Por isso, o slogan muito presente nas manifestações varguistas, "Queremos Getúlio", foi utilizado nas páginas da imprensa liberal para inventar um movimento coeso e unificado, o queremismo. Tratava-se de recurso para 
estigmatizá-los e impedir o aumento de sua participação política, seja por uma maior união entre as elites, seja pela supressão de suas vozes e ações.

\section{O queremismo como símbolo de identificação política}

O termo queremismo, inicialmente, era percebido como ofensivo por membros das fileiras getulistas. E, por isso, não era um elemento central de identificação política entre eles. É o que se pode sugerir, a partir de reportagem do Correio da Manhã de 9 de agosto de 1945, na qual o periódico propõe-se fazer um pequeno balanço do "queremismo" em Manaus-AM. Ele relata que, no domingo anterior, reunira-se "quase clandestinamente" "um grupo e figuras pouco conhecidas e que se deu o nome de Frente Democrática Getúlio Vargas". Formada supostamente pela elite integralista que agira naquele estado e em outros, a agremiação teria proposto filiar-se ao partido nacional que lançasse a candidatura do presidente (p. 14). Como podemos perceber, é o jornal que emprega a expressão, não o grupo propriamente dito. O nome escolhido para representá-lo girava em torno da personalidade de Vargas e de um compromisso ao menos formal com a democracia. Não sabemos se o termo queremismo era aceito por integrantes daquela organização. De qualquer forma, esta não se reconheceu oficialmente como um braço regional de um movimento nacional designado por ele.

É o mesmo Correio da Manhã, em coluna de opinião em 7 de agosto de 1945, que procura delinear a existência de um movimento coeso e organizado. No texto, críticas são tecidas contra manifestantes "queremistas" que teriam atacado comícios do brigadeiro na cidade do Rio de Janeiro. Na avaliação do periódico, "A onda crescente do 'queremismo'" estava relacionada à "provocação" e à "desordem"; pois, nos bairros de Madureira e Vila Isabel, "apareceram desordeiros de visível procedência governamental [...] o que prova a existência de um plano organizado para perturbar a marcha pacífica dessas demonstrações" (p. 4). Não se pode descartar a possibilidade de que houvesse apoio oficial aos referidos manifestantes naquelas circunstâncias. Contudo, tal suporte é antes pressuposto do que demonstrado empiricamente pelo jornal.

Ainda no plano das ilações, a reportagem de Rafael Corrêa de Oliveira, publicada no Diário de Notícias de 19 de setembro, critica as fontes obscuras do financiamento das manifestações. Ela relata o oferecimento de dinheiro de uma agência de publicidade ao jornal para que este veiculasse propaganda "queremista". Essa proposta teria sido negada por Orlando Dantas, proprietário do periódico. Queixando-se da "origem misteriosa" dos recursos, o repórter concluiu que o "queremismo" era "um movimento anárquico, sem responsáveis conhecidos, cuja vanguarda se recruta na suburra faminta das cidades e cuja direção parece refestelar-se nos agasalhos luxuosos das fortunas fáceis" (p. 4). A participação de empresários no financiamento dos atos em apoio a Vargas naquele ano é conhecida - como no caso de Hugo Borghi - , ainda que não documentada a fundo. No entanto, o jornalista inferiu, a partir de suas pistas, a existência de um movimento guiado tão-somente 
por fortunas privadas. Os raciocínios presentes nestas duas últimas reportagens, baseados em suposições, podem ter contribuído para delinear a existência de um movimento coerente e totalmente controlado pelo governo ou por empresários.

No entanto, queremismo, assim como tenentismo, não se mostra um conceito com conteúdo preciso. Um discurso de Osvaldo Aranha (então opositor do Estado Novo), feito na cidade de Santos-SP e publicado no Diário de Notícias em 20 de dezembro, fornece subsídios para essa discussão. Na ocasião, ele apregoou a necessidade de se "deter a maré nazifascista, que se renova no queremismo e no dutrismo, ameaçando confundir as consciências, intimidar a vontade popular e preparar a subversão do resultado inevitável das urnas" (p. 3). Posição contrastante pode ser vislumbrada em matéria do Diário Carioca de 25 de outubro. Nela, o jornal noticiou a reação de bancários contra seus dirigentes sindicais. Em sua opinião, tratava-se de uma reação dos primeiros contra a "campanha queremista-comunista pró-constituinte, por meio da diretoria do órgão de classe" (p. 3). Comunismo ou nazifascismo, nesses exemplos, são expressões de forte conteúdo emocional nos debates políticos do final da Segunda Guerra Mundial, especialmente em suas acepções negativas e, por isso não dão conta de explicar a orientação ideológica geral das manifestações varguistas. É certo que tanto comunistas quanto simpatizantes do fascismo chegaram a apoiá-las. Contudo, essas rotulações díspares negam quaisquer impulsos democratizantes nelas.

A composição social dos manifestantes também era delineada e qualificada de maneiras bastante contraditórias. O Diário Carioca de 21 de agosto, ao procurar descrever o suposto fiasco de comício relacionado aos primeiros na cidade do Rio de Janeiro, acusou a presença de um "rebutalho (sic.) indefinível das cidades, que não é operário, nem classe média, nem nada: são os sem profissão, os malandros, os rapazolas que escapam da campanha contra a vadiagem" (p. 2). Negar o caráter de classe das demonstrações de apoio ao presidente, seria um diagnóstico apressado ou um instrumento consciente da luta política para diminuir-lhes o significado? Tais questões também se aplicam às considerações do periódico sobre os pronunciamentos dos oradores do comício. Considerados desprovidos de lógica ou raciocínio articulado, eles foram equiparados a um tipo de rua, o "louco manso e às vezes exaltado que discursa e diz versos de sua autoria ao longo das filas de ônibus nas horas de maior aglomeração" (p. 2).

É curiosa a constatação oposta do colunista Danton Jobim no próprio Diário Carioca, em 31 de agosto, apenas alguns dias depois. Para ele, era um erro reconhecer somente "resíduos da injustiça social" entre os simpatizantes de Vargas; pois havia "operários honestos" naquele "movimento criminosamente inspirado por 'profiteurs' da ditadura". O jornalista chega a ensaiar uma explicação para o fenômeno, atribuindo-o, sobretudo, ao analfabetismo, tido como principal responsável pela adesão supostamente mística dos trabalhadores à figura do líder (p. 1). Atitude semelhante diante do "movimento" pode ser encontrada no jornal Gazeta de Notícias do dia 9 de outubro. Ao mesmo tempo em que as manifestações 
foram tratadas como a "pior forma de política", o periódico apontou a necessidade de se compreender suas causas e motivações. Sua proposta era reconhecer o "aspecto bom" delas e combater apenas o "continuísmo". No entanto, a explicação para o fenômeno difere da anterior, outra discrepância entre os sentidos do conceito: "Há, no queremismo, uma coisa que se salva e que deve ser compreendida nos seus devidos termos, na sua exata expressão [...] É o que ele tem de sentimento popular de gratidão" (p. 3). Ao que tudo indica, compreender rigorosamente a composição e as motivações das manifestações varguistas era uma forma de seus opositores definirem com maior precisão os modos de combatê-las ou limitá-las. ${ }^{4}$ De qualquer forma, o conceito de queremismo, apesar de ter sido empregado para descrever um movimento claramente definido, não continha contornos e limites claros.

No limite, o termo invertia o significado de algumas das principais reivindicações dos manifestantes. É o que aconteceu quando ele foi utilizado para designar um movimento que pretendia romper a ordem jurídica do país. Uma coluna de opinião do jornal Correio da Manhã de 25 de outubro afirmou que os "queremistas" não são cidadãos que "estejam usando do direito de opinar no pleito da sucessão"; pois, "insistindo na permanência do Sr. Getúlio Vargas no poder, estão, evidentemente, infringindo a lei, tomando uma atitude revolucionária" (p. 16). O jornalista Costa Rego, no mesmo jornal, em 7 de outubro de 1945 , criticou ferrenhamente um discurso de Vargas no qual vislumbrava uma justificativa para a modificação arbitrária de leis no futuro. Em sua opinião: “O queremismo, tido no começo por simples movimento afetivo em benefício de um homem, tomou [...] o caráter [...] de um golpe de fundo político" (p. 4). Nesses casos, as demandas pela candidatura presidencial de Vargas até o prazo para sua desincompatibilização ou pela sua participação como representante na elaboração da nova Carta - relacionadas à institucionalização da política - , foram representadas como tentativas dos seguidores de Vargas de suprimir as instituições então vigentes.

É importante ressaltar que o termo, em diversas ocasiões, foi recusado por simpatizantes do então presidente. Em 7 de agosto daquele ano, uma coluna de opinião do jornal A Noite, periódico carioca ligado ao governo Vargas e dirigido pelo jornalista André Carrazzoni, acusou em tom irônico as "colunas superdemocráticas dos órgãos que apoiam o Sr. Brigadeiro Eduardo Gomes" de ter inventado a "tal história de 'queremismo' ". Nessa versão, foram os opositores de Vargas os responsáveis pela cunhagem inicial do conceito. O texto procura ainda desfazer o suposto boato de que Vargas passaria o governo ao novo Ministro da Guerra, o general Góis Monteiro, e partiria para os Estados Unidos com o intuito de se desincompatibilizar e assim concorrer na eleição presidencial (p. 3, edição final). Nessas afirmações, é possivel notar a não aceitação da validade do conceito pelo órgão oficioso, pois um sentido negativo ou ofensivo é nele identificado.

O mesmo André Carrazoni, em edição de A Noite em 1 de setembro, reforçou essa posição. Segundo ele, a imprensa que transformou o "respeitável Sr. Major-brigadeiro Eduardo 
Gomes em orago da democracia teima em classificar de mera palhaçada a formidável reação popular batizada de 'queremismo' ". É possível notar que o uso do conceito, naquelas circunstâncias, não fora naturalizado, como ocorre atualmente no debate historiográfico. Ele era utilizado como instrumento de ataque por órgãos da imprensa oposicionista e, por isso, recusado por simpatizantes do varguismo. Carrazoni procurou uma explicação para tanto: "Ciosa dos privilégios outorgados pelo seu curioso credo liberal, não admite que fora dos círculos da truculenta irmandade outros homens tenham o direito de locomover-se, opinar, pensar, agir" (p. 2, edição final). Ainda que ligado diretamente a um governo autoritário, o colunista percebe bem o quanto o liberalismo das elites era excludente, uma das bases para a construção de opiniões e conceitos destinados a impedir a ampliação da participação política.

A percepção de que a terminologia procurava interferir nas disputas políticas foi várias vezes externada à época. Uma coluna do diário A Manhã, porta-voz do Estado Novo cuja direção ficara inicialmente a cargo de Cassiano Ricardo e Menotti Del Picchia, indicou tal intento no dia 5 de julho. Segundo o texto, as oposições ao governo pautavam-se tão-somente por injúrias e, por essa razão, inventaram o "queremismo" com dupla finalidade: "dum lado intrigar o chefe da nação com o candidato das forças majoritárias e, do outro, explicar o afeto, a gratidão e o entusiasmo do povo brasileiro pelo Presidente Vargas" (p. 4). Segundo o jornal, o propósito do conceito era abalar a relação de Vargas com o general Dutra, bem como apagar os motivos supostamente sentimentais e racionais para a adesão das camadas populares ao governo, entrevistos na retribuição à conquista de benefícios. Em suma, o periódico indica que o termo, como instrumento da luta política, mostrava-se uma invenção propositalmente redutora e ferina, destinada a impedir quaisquer articulações políticas ao redor de Vargas.

Apesar das incoerências e imprecisões do termo, bem como de seus significados pejorativos e ofensivos, muitos militantes varguistas começaram, entre os meses de agosto e dezembro daquele ano, a empregá-lo como símbolo de identificação política, provavelmente em razão do seu potencial unificador. Para tanto, urgia atribuir-lhe novos sentidos. Alguns destes podem ser encontrados nas páginas da própria imprensa liberal, que, às vezes, publicava vozes de seus próprios inimigos. A Folha da Manhã, periódico paulista de orientação liberal, por exemplo, chegou a veicular a fala do professor Bertho Condé, uma liderança "queremista", em 9 de outubro. Em suas palavras, os participantes do "movimento queremista" (em franca aceitação do termo) não eram destruidores da ordem legal; pois "negar que foi o povo que se reuniu é negar a própria evidência, e apodar o povo de desordeiro é um bom exemplo de seus sentimentos democráticos". Nesse caso, o líder reafirmou a legitimidade democrática das demonstrações de apoio a Vargas. Ademais, denunciou o autoritarismo do liberalismo das elites: "O que eles querem, mas não têm coragem de fazer ou propor, é que se cancele o direito de voto ao trabalhador, para ser apenas conferido aos plutocratas, bacharéis e coronéis" (p. 18). 
Se admitirmos o acerto dessa afirmação, no que tange à existência de intensa mobilização para barrar o voto operário, não há nenhuma contradição das elites com o pensamento liberal de John Locke. Afinal, segundo o filósofo inglês, havia diferenças de racionalidade entre proprietários e não proprietários. Estes, em momento posterior à distribuição de toda a terra, não podiam ser considerados plenamente racionais. Seus pensamentos não comportariam o nível das escolhas políticas, uma vez que sua vida seria limitada "da mão para a boca" (MACPHERSON, 1969, p. 238). O caráter autoritário do liberalismo, seja em sua gênese ou em suas versões nas últimas décadas, foi bem analisado por Maria Sylvia de Carvalho Franco. Pensamento que expressa um poder de classe, ele é altamente mistificador por trocar o sentido de todas as categorias que usa e inverter o significado do processo social: "a igualdade funda a desigualdade, a liberdade funda a opressão, a comunidade funda a sociedade dividida e estratificada, a democracia funda a dominação de uns poucos" (FRANCO, 1993, p. 45). Se tomado não apenas em sua natureza abstrata, mas em termos de sua concretização, o liberalismo não se revela menos autoritário, nem menos opressor. Domenico Losurdo, entre uma série de exemplos, destacou que as elites liberais da Inglaterra subjugaram irlandeses, nativos da América do Norte, negros e seus próprios trabalhadores livres em diversos momentos de sua história (LOSURDO, 2006, p. 12-36). No cenário político brasileiro de 1945, o pensamento e prática liberais atuaram para reprimir e excluir os trabalhadores da esfera pública. No entanto, suas promessas de liberdade e participação política universal parecem ter encorajado esses sujeitos a concretizá-las, embalados pelos efetivos ganhos obtidos em anos anteriores, conforme discutido anteriormente.

Naquele momento, a redemocratização não se restringia apenas ao Brasil. Entre os anos de 1944 e 1946, poucos países latino-americanos permaneceram sob regimes ditatoriais, apenas o Paraguai e um punhado de repúblicas da América Central e do Caribe (BETHELL; ROXBOROUGH, 1992, p. 5). Na Argentina, os trabalhadores aumentaram sua presença no cenário eleitoral em torno de Perón. Não é casual o conteúdo do editorial do Diário Carioca em 21 de agosto, em que "queremismo" é equiparado a "peronismo". Ambos, na acepção do jornal, eram exemplos de "primarismo político", ou seja, mobilizações em torno de um líder personalista que falseariam a representação liberal considerada legítima: "A ambição desmedida de um homem, aqui e além do Rio da Prata, tripudia impunemente sobre a soberania popular, negando ao país o direito de escolher livremente o seu supremo governante" (p. 4).

As semelhanças entre a experiência brasileira e a argentina podem ir além das resistências de suas elites à expansão da participação eleitoral. No peronismo, é possível identificar que, além de um tratamento mais humanizado e de melhores condições materiais de vida obtidos pelos operários, termos outrora símbolos de humilhação de classe adquiriram conotações e valores diametralmente opostos. O exemplo mais famoso refere-se à palavra descamisado. Esta havia sido utilizada originalmente pelos antiperonistas (sobretudo de orientação liberal), anteriormente à eleição de 1946, para se referir aos apoiadores de Perón. O símbolo de classe, a vestimenta, era empregado como sinal de status do opera- 
riado, melhor dizendo, como marca de sua inferioridade. O peronismo, por sua vez, apropriou-se do termo e inverteu seu significado simbólico, transformando-o em afirmação do valor da classe operária - como também faria com expressões como la negrada de Perón e las cabecitas negras (JAMES, 1988, p. 31). No caso do conceito de queremismo, algo semelhante acontece. Originalmente destinado a construir um inimigo político, ele passou a ser tratado por muitos como uma expressão que refletia o orgulho e a autoestima dos trabalhadores brasileiros em busca de maior participação política.

Afinal, a humilhação de classe era uma questão candente e explosiva naquele momento. O Diário Carioca de 24 de agosto deu mostras disso, ao comentar com virulência o desfecho de um comício udenista no Largo do Machado, na antiga capital federal. Segundo ele, "desordeiros" encerraram a reunião lançando seu "ódio assalariado" contra o palanque; a "mesma malta de vagabundos, de desclassificados a soldo do 'queremos' oficial" (p. 3). A matéria é repleta de qualificativos desse teor. Importa destacar que o termo malta, presente no vocabulário político da oposição a Vargas à época, foi também empregado pelo brigadeiro Eduardo Gomes. Este afirmou, no Teatro Municipal do Rio de Janeiro, que não necessitava dos votos da malta de desocupados que frequentava os comícios varguistas. Diante disso, Hugo Borghi consultou o dicionário e afirmou que tal palavra significava - além de bando, súcia -, um grupo de operários que percorriam as linhas férreas levando suas marmitas, e afirmou então que o brigadeiro desprezava o voto dos marmiteiros. Tal episódio contribuiu para que o último fosse vislumbrado como candidato dos "grã-finos" e a UDN como "partido dos cartolas" (BENEVIDES, 1981, p. 45). Nesse caso, o artifício do empresário tocou em cheio num símbolo de humilhação de classe, a marmita. Esse esforço pode ser explicado, em parte, porque o conceito de queremismo não se prestava mais a tanto, uma vez que seus sentidos passavam por amplo processo de positivação.

É o que se pode sugerir, pelas próprias páginas da imprensa oposicionista. Uma reportagem do Correio da Manhã de 1 de agosto, por exemplo, narrou uma cerimônia destinada a articular em âmbito nacional, no então Distrito Federal, diversas manifestações pró-Vargas espalhadas pelo país. Detalhe importante indicado pelo jornal é que, na ocasião, palavras como "queremistas" e "queremismo" foram oficializadas. Essa informação sugere que esses termos, outrora recusados por tais sujeitos, passaram a fazer parte de seu vocabulário, tornaram-se símbolos de sua identificação política. Essa transformação é evidenciada na fala de Aristeu Santana, um dos oradores, que iniciou seu discurso da seguinte forma: "O nosso queremismo [...] que no começo foi uma fantasia nas hostes do brigadeiro, se transformou em realidade" (p. 14). Em outras palavras, a palavra, enquanto invenção linguística para unificar movimentos esparsos que se pretendia rebaixar e atacar, acabou sendo empregada justamente por pessoas cuja ação ela visava a suprimir. Retomando as reflexões de Koselleck, é apenas então que esse "ismo" se transforma em recurso para a ordenação e a mobilização de grupos estruturalmente desarticulados.

É o que confirma seção do Correio da Manhã de 21 de agosto. Nela, é possível acom- 
panhar a cobertura de pronunciamentos públicos a favor de Vargas no Largo da Carioca, na antiga capital federal. Na ocasião, um jornalista não identificado fez um discurso assumindo fazer parte do "queremismo". Referindo-se a este último, ele disse: "O povo transformou o significado da palavra que foi inventada [...] pela imprensa oposicionista. A palavra, que não se encontra nos dicionários, havia sido aplicada no mau sentido. $O$ povo aceitou o desafio e surgiu então o slogan, que é a bandeira do povo: 'Nós queremos Getúlio'" (p. 14). O caminho descrito pelo orador não é verossímil. O termo provavelmente foi derivado pela imprensa liberal do slogan proferido pelos manifestantes, não o contrário. De qualquer forma, ele sinalizou uma inversão do sentido original da palavra, de forma positiva. Tanto esse exemplo quanto o anterior indicam que havia um processo social de ressignificação do termo. Este último passava a ser utilizado para neutralizar os ataques dos opositores de Vargas, bem como transformar uma pluralidade de fenômenos regionais e descentralizados num movimento nacional unido e articulado.

Uma inversão bem clara de significado da palavra aparece na coluna de Mattos Filho publicada no jornal A Manhã, em 9 de agosto. Nela, ao lado da defesa da candidatura Dutra, torna-se evidente a importância da disputa conceitual:

Somos 'queremistas' no sentido de significar o 'queremismo' um movimento de reação aos detratores da obra social, política e administrativa do Presidente Vargas. [...] Queremos, portanto, Getúlio, ou seja, o respeito à autoridade pública, na qual se respeita o povo e não facções; queremos o governo de partido, de ideias e não de nomes, portanto, batemo-nos, no pleito de 2 de dezembro próximo, com o voto, 'arma dos cidadãos', na frase ruista, pela Presidência na República, do Sr. Eurico Dutra e pela presidencial à frente do P.S.D., o grande partido nacional do Sr. Getúlio Vargas. Nessas condições, somos, fora de quaisquer dúvidas, 'queremistas', nós, isto é a maioria da Nação (p. 4, grifo meu).

Em outras palavras, Mattos Filho procura reverter o sentido desabonador do conceito e de suas derivações. Ele provavelmente respondia às posições de que este último designaria um fenômeno meramente personalista destinado a perpetuar a ditadura. Ao contrário, em sua opinião, tratar-se-ia de termo que nomeava um movimento, objetivando a instituição da política partidária em torno do legado do governo Vargas. Tal definição procurava definir o sentido das lutas, assim como apelava para os manifestantes varguistas se unirem em torno do conceito de queremismo.

Nos meses seguintes, essa tendência seguiu cada vez mais forte. É o que pode ser notado em reportagem do Diário de Notícias de 4 de outubro. Nela, aparece a cobertura de novo evento em apoio a Vargas e a voz de um de seus participantes. José Duarte, apresentado como jornalista (entre aspas pelo jornal, como forma de desqualificar suas credenciais), atacou primeiramente membros da "imprensa livre". Em seguida, dirigiu-se criticamente ao general Dutra por este ter taxado as movimentações agrupadas sobre o termo "queremismo" de afetivas. Servindo-se então de palavras distintas, mas com sonoridades semelhantes, ele procurou mudar a adjetivação e o sentido do conceito: "Um candidato 
disse, em São Paulo, que o queremismo é um movimento afetivo. Não é não. O queremismo é um movimento efetivo de justiça" (p. 6). No jornal $A$ Noite, de 5 de outubro, desta vez de um ponto de vista governamental, a fala de Fernando Costa, interventor paulista, reforça o processo de ressignificação, ao afirmar que o termo designava "um movimento popular que se explica como uma expansão irreprimível do sentido de gratidão do povo para com o grande chefe da nação" (p. 3, edição das 11H). Nesses casos, não há uma tentativa de negar o termo pelos partidários de Vargas, como vimos anteriormente, mas sim de conduzir a luta política em seu interior, em verdadeira disputa pelo seu significado. Nesta batalha conceitual, não há somente um jogo de palavras e sentidos. Há igualmente uma acirrada competição para se definir quem pode ou não se expressar e opinar na arena política.

Mais uma fala de liderança, desta vez de comitê pró- candidatura Getúlio Vargas de Pelotas-RS, pode ser analisada no jornal A Noite, de 5 de outubro. Na reportagem, Gentil de Oliveira apelou para que seus companheiros ingressassem no Partido Social Progressista. Em sua opinião, todos faziam parte de um movimento em torno da pessoa de Vargas com o único fim de elevá-lo à Presidência da República. Porém, segundo ele, "o Queremismo não foi registrado como partido político. Nessas condições, não tivemos dúvidas em associarnos a um partido que propugne por essa candidatura" (p. 8, edição final). Nesse exemplo, é possivel destacar a aceitação do termo por um dos dirigentes das manifestações, bem como sua grafia pelo jornal oficioso que tanto recusara sua validade; em letras maiúsculas, como se fosse um substantivo próprio digno do mais alto respeito. Desse modo, mais do que descrever um fenômeno, o conceito pretende criá-lo e canalizar suas forças.

O grau de aceitação do termo fica bastante evidente na propaganda dos manifestantes. O jornal Folha da Noite, de 29 de setembro, por exemplo, reproduziu folheto de convocação para um comício programado para a Praça da Sé, na capital paulista, no dia 3 de outubro, com o seguinte chamado: “Trabalhadores! Queremistas!" (p. 1). As duas palavras, utilizadas paralelamente, procuravam designar o mesmo grupo social, ou unir grupos distintos sob uma mesma bandeira. Eis uma tentativa de se transformar o conceito ou seu derivado em polos de identificação política operária. Nesse caso, é possível imaginar que o termo não pretendesse simplesmente criar, a partir do zero, tal associação. Esta, provavelmente, já tinha sido relativamente difundida entre os trabalhadores àquela altura, como indicam as referidas falas de lideranças. $E$, ao que tudo indica, muitos sujeitos convergiram em torno do termo. A Manhã, de 19 de outubro, traz indícios desse processo. Na ocasião, o periódico publicou telegrama dirigido a Vargas em nome de Agapito Caujo e família, com a seguinte declaração: “Mui gostosamente associamo-nos ao 'Queremismo' [...] Só a inteligência patriótica de V. Excia fará o Brasil forte" (p. 3). Como se pode notar, o conceito se transformara em instrumento de mobilização política.

Enfim, ecos desse debate podem ser encontrados na campanha eleitoral de 1950, quando Vargas disputou a Presidência da República pelas urnas. Em seu arquivo pessoal, encontra-se interessante folheto escrito em versos por um de seus simpatizantes, de forma 
semelhante a uma composição de cordel. O autor se declara Francisco Alves Nascimento, de Paranavaí-PR, e procura traçar um corte no tempo com a ascensão de Vargas ao poder. Em suas palavras, sobressai a percepção de ganhos pelos trabalhadores no governo deste último:

Trabalhadores se lembrem/ do nosso Brasil antigo/ antes de Getulio Vargas [...]/ Trabalhador aquele tempo/ eram antes sem valia/ trabalhava como escravo/ sem nenhuma garantia [...]/ O Getulio fez justiça/ acabou com o banditismo/ amparar os trabalhadores/ pôs freio ao capitalismo/ deu exemplos de justiça/ e provas de socialismo/ Ele implantou no país/ o regime e a disciplina/criou as leis trabalhistas/ foi inspiração divina. ${ }^{5}$

É curioso ainda o modo como o autor se apresenta: "Me tratem de queremista/ eu com isso tenho muito orgulho". Nas entrelinhas, é possivel identificar que ele recusa um sentido negativo para o qualificativo, transformando-o em símbolo de identificação política e de autoestima de um grupo social. Nesse debate, Avishai Margalit sustenta que é impossivel alguém de status social inferior permanecer imune à humilhação externa (MARGALIT, 1996, p. 25). De qualquer forma, como pudemos notar no caso dos trabalhadores alemães, exposto por Norbert Elias, ou dos trabalhadores argentinos, analisado por Daniel James, humilhação, orgulho e autoestima não são gestados apenas nos indivíduos. Esses elementos também são engendrados socialmente entre grupos e classes. Portanto, esses sentimentos estão sujeitos à mudança histórica. Como sugeriram os referidos autores, eles podem ser atenuados em determinadas circunstâncias, com o crescimento da autoconfiança das camadas mais baixas da sociedade. É o que parece ter acontecido com os trabalhadores brasileiros nas circunstâncias da redemocratização de 1945, processo que subsidiou a ampla transformação dos sentidos do conceito de queremismo: de inimigo político a símbolo de identificação política operária.

\section{Considerações finais}

O termo queremismo pode ser situado historicamente como elemento importante das disputas políticas, durante a redemocratização de 1945. Conforme procurei demonstrar, sobretudo por meio da imprensa, trata-se de neologismo derivado do slogan "Queremos Getúlio" pelos opositores do então presidente para combater os manifestantes favoráveis à sua permanência no poder. Para tanto, agrupava sob o mesmo rótulo fenômenos distintos espalhados por todo o território brasileiro, os quais não possuíam, pelo menos num primeiro momento, unidade nem direção central. Verdadeira estratégia para a construção de um inimigo político, de maneira análoga à noção de tenentismo, essa construção linguística supunha a existência de um fenômeno incivilizado, ameaçador, despido de consciência política, empenhado tão-somente em perpetuar a ditadura do Estado Novo. Em outras palavras, algo que deveria ser eliminado da esfera pública, em consonância com a doutrina e as práticas liberais, que, tanto no Brasil como em outras partes do mundo, foram - e continuam sendo - mobilizadas para conter o avanço da participação política dos trabalhadores. 
Contudo, ao longo daquele ano, os sujeitos que reivindicavam a candidatura presidencial de Vargas ou sua participação em futura Assembleia Constituinte, foram capazes de ressignificar o conceito de queremismo. Percebendo seu potencial unificador, eles trataram de inverter seus significados desabonadores e transformá-lo em símbolo de identificação política e de valorização dos trabalhadores. Estes, embalados pela percepção de que haviam obtido ganhos durante o governo do primeiro, convergiram em larga medida em torno um movimento nacional, especialmente no segundo semestre de 1945. Ao servirem-se do referido termo para nomeá-lo, escolheram travar a luta política no âmbito de formulação conceitual voltada a diminuir o valor de seu grupo social. E, de certa forma, inverteram os termos da equação, dado que a transformaram justamente em veículo de seu renovado autovalor na sociedade, expresso em suas intenções de escolher seus representantes. Portanto, a noção de queremismo, nessa nova acepção, foi instrumento de defesa da participação política institucional daqueles sujeitos.

\section{Referências}

ABREU, A. A. et al. (Org.). Dicionário histórico-biográfico brasileiro. Rio de Janeiro: Ed. FGV, 2001.

BAHIA, J. Jornal, história e técnica. São Paulo: Ática, 1990.

BENEVIDES, M. V. A UDN e o udenismo: ambiguidades do liberalismo brasileiro. Rio de Janeiro: Paz e Terra, 1981.

BETHELL, L.; ROXBORUGH, I. (Org.). Latin America between the Second World war and the Cold War (1944-1948). Cambridge: Cambridge University Press, 1992.

BORGES, Vavy Pacheco. Tenentismo e revolução brasileira. São Paulo: Brasiliense, 1992.

CABRAL, Elza Borghi de Almeida. O queremismo na redemocratização de 1945-1984.

Dissertação (Mestrado em História) - Universidade Federal Fluminense, Niterói, 1984.

CAPELATO, M. H. Os arautos do liberalismo: imprensa paulista (1920-1945). São Paulo: Brasiliense, 1988.

CARLYLE, T. Thomas Carlyle: selected writings. Harmondsworth: Penguin Books, 1980.

EDELMAN, M. Constructing the political spectacle. Chicago: University of Chicago Press, 1988.

ELIAS, N. Os alemães: a luta pelo poder e a evolução do habitus nos séculos XIX e XX. Rio 
de Janeiro: Zahar, 1997.

FERREIRA, J. Imaginário trabalhista: getulismo, PTB e cultura popular (1945-1964). Rio de Janeiro: Civilização Brasileira, 2005.

FERREIRA, J. (Org.). O populismo e sua história: debate e crítica. Rio de Janeiro: Civilização Brasileira, 2001.

FRANCO, M. S. de C. All the world was America. Revista USP, São Paulo, n. 17, p. 30-53, mar./maio 1993.

GOMES, A. de C. A invenção do trabalhismo. Rio de Janeiro: Ed. FGV, 2005.

JAMES, D. Resistance and integration: peronism and the Argentine working class, 19461976. Cambridge: Cambridge University Press, 1998.

KOSELLECK, R. Futuro passado: contribuição à semântica dos tempos históricos. Rio de Janeiro: Contraponto; Ed. PUC-Rio, 2006.

LACERDA, C. O rato Fiúza. Rio de Janeiro: Moderna, 1946.

LOSURDO, D. Contra-história do liberalismo. Aparecida: Ideias \& Letras, 2006.

MACPHERSON, C. B. The political theory of possessive individualism: Hobbes to Locke. London: Oxford University Press, 1969.

MARGALIT, A. The decent society. Cambridge; London: Harvard University Press, 1996.

MOORE JUNIOR, B. Injustice: the social bases of obedience and revolt. New York: M. E. Sharpe, 1978.

QUELER, J. J. "Oh! Gegê! vem nos salvar!": propaganda política popular (1945-1953). Revista Tempo, UFF, Niterói, n. 38, v. 21, p. 137-156, 2015.

ROSANVALLON, P. Por uma história conceitual do político. Revista Brasileira de História, São Paulo, n. 30, v. 15, p. 9-22, 1995.

SODRÉ, N. W. História da imprensa no Brasil. Rio de Janeiro: Mauad, 1999.

SOUZA, M. do C. C. Estado e partidos políticos no Brasil (1930-1964). São Paulo: AlfaOmega, 1976. 


\section{Notas}

1 O autor alinha-se ao trabalho de Gomes (2005) sobre o governo Vargas e a legislação trabalhista.

2 Como todas as citações de jornais referem-se ao ano de 1945, indicarei apenas o dia e o mês no corpo do texto.

3 Tais metáforas desabonadoras transcendiam as fileiras do getulismo. É o que indica a série de artigos escritos por Carlos Lacerda para o jornal Diário Carioca contra ledo Fiúza, então candidato do PCB, nos quais este último é tratado como "rato" (LACERDA, 1946).

4 Neste debate, é possível sugerir ecos, provavelmente indiretos, das resistências ao Cartismo na Inglaterra do século XIX. Esse movimento de base operária pleiteava, entre outras coisas, a institucionalização do sufrágio universal. Em 1839, Thomas Carlyle, um de seus mais fervorosos opositores, defendeu a seguinte postura das elites frente a seu avanço: "How inexpressibly useful were true insight into it; a genuine understanding by the upper classes of society what it is that the under classes intrinsically mean; a clear interpretation of the thought which at heart torments these wild inarticulate souls, struggling there, with inarticulate uproar, like dumb creatures in pain, unable to speak what is in them! [...] Perfect clearness on it were equivalent to remedy of it" (CARLYLE, 1980, P. 155).

5 Arquivo pessoal Getúlio Vargas, CPDOC-FGV, GV ce 50. 08/ 09. 00/ 53. Citado em: Queler (2015, p. 150).

Jefferson José Queler. Doutor em História pela Universidade Estadual de Campinas (UNICAMP). Professor Adjunto do Departamento de História da Universidade Federal de Ouro Preto (UFOP) - Instituto de Ciências Humanas e Sociais (ICHS) - Rua do Seminário, s/n, Mariana/ Centro, Minas Gerais, 35420.000. Este estudo contou com o financiamento do Conselho Nacional de Desenvolvimento Científico e Tecnológico (CNPq). Uma versão preliminar dele foi apresentada em encontro da Asociación de Historiadores Latinoamericanistas Europeos (AHILA), Berlim, em 2014, com o apoio de recursos da Coordenação de Aperfeiçoamento de Pessoal de Nivel Superior (CAPES). Agradeço muito aos colegas deste evento, bem como aos pareceristas anônimos desta revista, pelas críticas e sugestões.

Recebido em 07/11/2015

Aprovado em 12/07/2016 